\title{
Study of Using Applications of Artificial Intelligence in Performance of Financial Markets
}

\author{
Raed Fadel Jawid, Dean of Imam University College, Iraq
}

\begin{abstract}
In an attempt to revive the stock market in Egypt and revitalize it to fulfill its developmental role, the Egyptian government has pursued a program of economic and financial reform aimed at improving the regulatory environment for the work of that market and removing all restrictions on foreign exchange transactions for foreign investors on the Egyptian Stock Exchange, so this program allowed free movement of entry and exit of the heads money without any restrictions despite differing opinions about the freedom of movement of capital.
\end{abstract}

\section{KEYWORDS}

Artificial Intelligence, Egyptian Government, Financial Markets

\section{INTRODUCTION}

The stock market is one of the most important sub-markets of the money market and is characterized by being a long-term investment when compared to the money market and its main function is to collect community savings and direct them to buy securities. In this market, savings are converted into capital and loans to institutions that carry out various activities in society, which increases real investment and hence increases employment and growth rates in the national economy.

In an attempt to revive the stock market in Egypt and revitalize it to fulfill its developmental role, the Egyptian government has pursued a program of economic and financial reform aimed at improving the regulatory environment for the work of that market and removing all restrictions on foreign exchange transactions for foreign investors on the Egyptian Stock Exchange, so this program allowed free movement of entry and exit of the heads Money without any restrictions. Despite differing opinions about the freedom of movement of capital, however, with the increase in the process of globalization of financial markets in the past two decades, the phenomenon of financial liberalization accelerated and the role of foreign capital transfers increased during the nineties of the last century and the beginning of the current century, where the value of capital financial transactions constituted about five times the rates of trade And with regard to developing countries, the movement of financial flows to these countries has accelerated in various forms, including investments and others in the portfolio..

\section{THE IMPORTANCE OF THE STUDY}

As a result of the shortage of domestic funding sources in developing countries to support their development projects, I began to search for alternative external sources to advance development levels 
represented in several forms, including foreign loans and foreign investment. Due to the seriousness of relying on these loans to finance their economic development operations, attention has turned to the use of foreign investment, both direct and indirect, as an engine of economic growth that contributes to increasing the productive capacities of the local economy. In view of the wide scope of the study of foreign investment, and based on the importance it plays in the receiving developing economies, it is important to know the role of foreign investment in emerging stock markets in general, and the Egyptian Stock Exchange in particular

\section{THE PROBLEM OF STUDY}

Although many developing countries pursue economic and legal policies that increase the flows of indirect foreign investment to developing countries, there are still risks and obstacles that indirect foreign investment is exposed to, thus limiting the amount of foreign capital that these countries benefit from. Therefore, the study addresses the role of indirect foreign investment in revitalizing the Egyptian Stock Exchange as a model for the study.

The aim of the study

The study aims to answer what are the advantages of indirect foreign investment in the countries you are looking for. And the extent of foreign investment in direct participation in the growth and revitalization of the stock market in Egypt.

\section{Hypothesis of Study}

The study is based on the hypothesis that indirect foreign investments play a big role in stimulating the movement of financial markets, including the stock market in Egypt, during the study period, which confirms the importance of economic and financial reforms to improve the regulatory environment for the work of that market and remove restrictions on foreign exchange transactions for foreign investors.

\section{The Study Plan}

The study was divided into three sections:

1. The concept of the stock market and its components, and the advantages of investing in the stock exchange.

2. To review the indirect foreign investment in the stock market and address its forms and limitations in emerging countries and the risks associated with these investments in the portfolio.

3. To study the effect of indirect foreign investment on activating the Egyptian stock market by analyzing the net movement of foreign investors' transactions on the Egyptian Stock Exchange during the period 2010-2020 and the repercussions of the global financial crisis on the Egyptian Stock Exchange. Finally, review the results, recommendations and tables

\section{THE CONCEPT OF THE STOCK MARKET AND ITS COMPONENTS}

The decrease in the capital needed to finance and implement investment programs is one of the most important obstacles to economic development in developing countries, and the stock market is one of the most important mechanisms for providing these funds, as it represents the link between the surplus and deficit sectors which lack the liquidity to finance the investment.

Although the stock market is recent in relation to other markets, it has recently evolved considerably, both in terms of regulation or the capabilities and facilities available to its employees, to the point that it has received great attention in developed and developing countries alike, due to the large investments your financial position. The stock market is one of the elements of the financial market in any country and the backbone of the capital market. (The Soldier, 2016, 52) 
The financial sector usually turns to the units that play the role of financial intermediation between the money savers and their investors, in a way that affects the real activity in the economy. (Key 2017, 81)

As shown in Figure 1, the structure of the financial market, which is divided into: (Al-Ahmad, 2017, 46)

\section{Money Market}

That deals with short-term loans, the most prominent of which are treasury bills and negotiable bank deposit certificates.

\section{Capital Market}

It deals in medium and long-term loans. Examples include government stocks and bonds issued by the state's public treasury. Hence, it does not depart from being an institutional framework through which the sectors of the capital surplus meet the sectors of capital deficit. (Ford, 2015, 77). This market is in turn divided into two main parts:

i) Institutions that work in funds and long and medium-term loans such as industrial development banks and real estate banks.

ii) It is the stock market, which is one of the most important sub-markets of the money market and is invested in it by purchasing securities (stocks, bonds ...) which are the subject of our study in this research. In terms of functionality, this market is divided into two main markets: the issuance market (the primary market) and the trading market (the secondary market). As in Figure 1 (AlMubdar, 2016, 54)

In the primary market, securities transactions are carried out for: (22, 2019, Miles)

A. Under establishment companies whose shares are offered for public subscription for the first time.

B. Increase the capital of companies already existing from the IPO companies after incorporation.

C. Issuing bonds when long-term loans are needed for the purpose of increasing financial resources to meet the required investment needs, which represents an alternative to or from the banking system to borrow from it.

D. Increase the capital of companies already existing from closed underwriting companies. In this case, the subscription is limited to the founders and current shareholders of the company.

In the secondary market, securities transactions are issued after issuance, i.e. after distribution by a specialized financial institution, in which securities that offer subscription to the public are traded through the issuance market where demand and supply meet, and the sale of securities offered for trading is aimed at obtaining liquidity. This market is called the stock exchange. The companies listed in this market must abide by several conditions related to the degree and quality of financial disclosure about the performance of these companies. (Haddad, 2015, 102)

The secondary market may take two forms: (Shapiro, 2013, 152)

- The organized (official) market: It is the market in which the sale and purchase of securities listed on the stock exchange during the execution sessions is distinguished, as it is characterized by the presence of a specific place where the buyers meet to buy and sell (the stock exchange).

- The unorganized (parallel) market: It is the market that specializes in trading in securities, whether registered or unregistered in the stock exchange, and is dealt with through negotiation 
Figure 1.

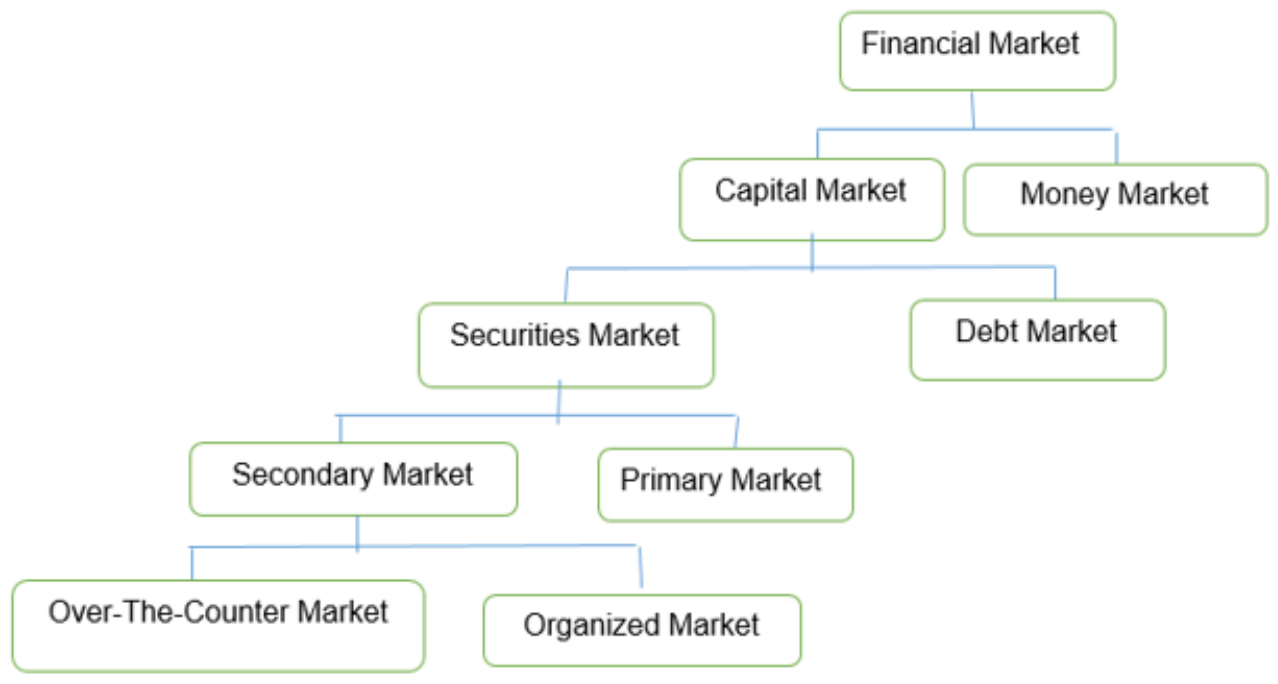

and without being subject to rules or procedures in which dealings are conducted outside the stock market halls.

Through the trading market, the government can achieve economic goals, the most important of which are:

- Mobilizing the savings necessary to finance economic development operations in a noninflationary manner. It can offer treasury bonds to make them accessible to society members, not just banks.

- Increasing the effectiveness of monetary policy as the trading market enables the central bank to use the open market policy effectively.

- $\quad$ Giving banks an opportunity to utilize their excess liquidity for short periods through trading treasury bonds, as they reassure banks that they can easily restore the quick liquidity they need.

The stock market is defined as (a financial market in which securities are exchanged for shares and bonds for the purpose of indirect investment, whether by local or foreign investors. Traders on the stock exchange are obliged to observe the laws and regulations that regulate dealing in them, and a stock management body is responsible for overseeing the implementation of these Laws. (AlAreed, 2018, 16)

It can also be considered (an economic and electoral forum through which knowledge of economic strength in relation to parties dealing in the market leads to efficient allocation of capital in the national economy and improvement of the efficiency of economic resources). (Beaver, 2017, 20)

We must point out that the stock market in many developing countries has witnessed rapid developments represented in liberalizing their markets from restrictions and seeking to accommodate developments from financial tools and institutions, and thus working to increase the attractiveness of their markets to local and foreign investments, as well as their competitive ability in providing 
financial services as part of a program Economic reform and structural adjustment in light of the liberal economy system adopted by most developing countries since the mid-seventies. Despite this development, however, not all countries were equal in this development, so what appeared in the literature of global investment in the late twentieth century is known as (emerging markets) in order to refer to stock markets in developing countries that have made a good way from economic progress and to distinguish them from those markets In all economies of developed and developing countries.

Consequently, we can call the stock market in any emerging market country (emerging) if two basic features are applied to it: (Al-Taweel, 2016, 85)

A - The presence of this market in a developing economy is still facing fundamental problems at the political, economic and social levels.

B - The market is in the process of growth, that is, it is markets of small sizes compared to global markets, but they have multiple capabilities to continue growth and progress.

The emerging stock market is represented by the growing Asian economies dependent on exports, the newly privatized markets in Latin America, as well as those in the countries of the new capitalist system in Eastern Europe, as well as some African countries. The number of emerging stock markets listed in the IFC index reached 46 by the end of 2016, including 16 in East and South Asia, 10 in Latin America, and 20 in Africa, Europe and the Middle East, including Egypt. (Mobius, 2016, 110)

\section{The Advantages of Investing In The Stock Exchange}

Through The Stock Exchange

- Real-time transfer of ownership of the securities traded to ensure the safety of transactions and increase their efficiency.

- Protecting the rights of investors through the means introduced by the investment laws for the protection of the investor. Achieving market safety, among which is the establishment of a settlement and insurance guarantee fund Against risks.

- Regulating the issuance market and facilitating procedures for establishing companies.

- Regulating the trading of securities in the secondary market, while developing the stock exchange infrastructure establishing an effective automated trading system for securities.

- Providing diversification of the major portfolios of countries, large financial institutions and large dealers.

- Efficient allocation of capital and improvement of the efficiency of the resources invested in the best performing projects ", because the stock market is an electoral economic forum through which economic power is achieved with respect to the parties dealing in the market. $(6,2016$, Levine)

Factors Affecting The Stock Market

A. Inflation: Inflation is the primary enemy of capital, because it represents a decrease in both its value and the purchasing power of savings, as a result of which will be the rapid disposal of those assets that have lost their value and replacing them in kind. (Al-Najjar, 2012, 14)

B. Speculation: It is done with the intent to take advantage of the price fluctuations of securities, as it is based on speculators' estimates. However, it is not possible to consider all speculation with a negative indication in the stock markets, as it helps, if based on economic facts, to flourish and stimulate the stock market. In cases where speculation occurs quickly and suddenly, it may cause stock exchanges to collapse. Therefore, severe penalties are often imposed for any speculator trying to influence the stock market prices by any means of fraud. (Shahada and others, 2016,56) 
C. Transmission of infection between stock exchanges: If there is a decline in one of the stock exchanges or an evolution in the prices of some securities, then his infection will soon be transferred to the rest of the stock exchanges, based on the extent of the contact between the stock exchanges with each other.

\section{FOREIGN DIRECT INVESTMENT IN THE STOCK MARKET}

Most developing countries suffer from a number of problems that affect their development plans, the most important of which are the lack of capital, which necessitates the necessity of appropriate programs to finance development plans in these countries, both through domestic and foreign sources. Examining these sources shows us several facts, including insufficient domestic sources of funding resulting from a gap in domestic resources between investment and savings, as well as a gap in external relations between exports and imports. Likewise, the risk of relying on external sources of financing, such as external borrowing, as the debt burden increases, so that debt service amounts become greater than these countries receive from new loans and economic aid, which some economists call the reverse flow of resources. The external debt crisis may have important political and economic dimensions that are depleting the reserves of debtors countries of foreign exchange and then weakening their ability to import, low investment rates and then employment and growth rates and the inflation that they withdraw from. (Atallah, 2019, 68)

From here it became clear the necessity of resorting to another safer source, which is the development of foreign investment, both direct and indirect. Investment may be real or financial, and financial investment reflects investments that do not result in the transfer of ownership of capital goods from one party to another without causing an increase in the productive capacity of society, such as buying stocks, bonds and other securities. On the other hand, the investments may be internal or foreign. Foreign investment is a type of investment ((it expresses the ownership of one of the institutions or a person in one state for the assets of institutions operating in another country. Foreign investment is divided into two types which are direct, which involves the participation of the foreign investor in the management of the project with the national investor in the case of investment The subscriber or his complete control over management and organization in the case of his absolute ownership of the investment project, and indirect and the area of interest in this research and therefore we are subject to study in the following points:

\section{The Concept of Foreign Direct Investment}

The concept of indirect foreign investment or foreign investment in securities includes those investments directed to purchase securities issued by public or private bodies in developing countries, that foreigners have the right to manage the project or make decisions or control those projects related to their investments) (IMF, 2016, 95)

From this definition, we find that foreigners are not entitled to manage the project, to make decisions or to monitor, while they have the right to receive a return for their participation. Therefore, it differs from foreign direct investment in that the transfer is usually limited to the capital component only, and it is considered a short-term investment if we compare it with foreign direct investment.

\section{Forms of Indirect Investment In The Stock Market}

\section{Perspective of The Method of Obtaining Financial Assets}

In this perspective, FDI takes the following pictures (IFS, 1999, 35)

i) Buying securities directly from the stock exchange: By that type, it means direct dealing with foreigners by buying and selling on stock exchanges, whether from the primary or secondary market, so that the investor's contribution to the company does not exceed 10 percent because 
exceeding this ratio means turning it into a foreign direct investment that provides the foreign investor an opportunity Take control of the company. If we look at this kind in emerging countries, we find that it has increased from $\$ 3.1$ billion in 2015 to $\$ 34$ billion in 2018 , then decreased to $\$$ 14.2 billion and $\$ 23$ billion in 2018-2019, respectively, as a result of the Mexico crisis. Likewise, this type of influx witnessed a decrease in the second half of 2017, with the five countries most affected by this crisis being Indonesia, Malaysia, the Philippines, South Korea, and Thailand, where an external influx was estimated at about 12 billion dollars, which represents about 10 percent of The combined GDP of these countries. This was the result of the Southeast Asian crisis. (Hassan, 2019, 62)

ii) International investment funds: They collect money from investors to invest in many markets outside the mother country, and then we find what is international and what is regional. This type of investment has many advantages, whether for the foreign investor or for local companies in the local market of the mother country.

It gives the investor the opportunity to diversify into international stocks at a low cost, and thus reduces the degree of risk to which he is exposed, especially in light of managing this portfolio of specialized managers. As for local companies, it gives them an opportunity to access global markets and reduce the cost of obtaining capital (UN, 2018, 188)

iii) Global issuances: Several emerging markets have benefited from foreign capital through issuances that are registered in international stock exchanges, which are deep, allowing companies to rapidly invest in a volume of securities that are difficult to invest in the local market, and to expand the capital base outside the national borders, and from Then reducing the cost of capital, and usually these issues require the availability of some conditions in the exporting company in terms of being distinguished in the local market in the field of their production specialization, and if they enjoy good financial and administrative performance, and that they have periodic data and reports prepared in accordance with computer standards Accepted internationally, and some global markets require compliance with international accounting systems.

Global issuances of international and American Depository Certificates increased during the period (2010-2016) with an average growth rate of about 30 percent, and those issuances represented at the end of 2015 about 6 percent of the total market value of emerging market stocks in the IFC Index. (IFC, 2018, 79)

iv) Venture Capital Funds: These funds provide financing, administrative and technical expertise for companies that are not registered on the stock market in particular for small and medium-sized companies and for which the privatization program is applied, provided that a good growth rate is expected in the future through which the fund will achieve its profits. The existence of this type of fund requires a stable economic environment, an active and liquid financial market, and a transparent legal framework. IFC statistics indicate in 2016 that venture capital funds invested $\$ 196$ million in 49 of the venture capital funds in emerging markets, which represented about 8.6 percent of the market capital of these markets, and Asia and Latin America accounted for 59 percent of these funds (IFC, 2017, 25)

\section{The Perspective of Multiple Access To Securities}

In this case, we find that foreign direct investment may be individual and intended to purchase only one asset, even if the unit purchased from that asset is repeated. And multiple if it includes two or more types of financial assets, which is called (the portfolio of securities), an expression that means the sum of what the investor owns of financial assets. 


\section{THE DETERMINANTS OF ATTRACTING FOREIGN DIRECT INVESTMENT IN THE STOCK MARKETS OF EMERGING COUNTRIES (FACTORS OF ATTRACTION AND EXPULSION)}

The new world order is characterized by globalization, the liberalization of international trade, and the freedom to transfer capital. Increasing the volume of foreign investment in direct and indirect quality. Countries seek in every way to create a more favorable environment for investments with the need to take into account their development requirements and adopt policies that would achieve the maximum benefit from these investments. Avoid the negatives. Caused by it.

With the beginning of the twenty-first century, there has been a surge in foreign capital flows to emerging markets. For example, the volume of foreign investment abroad increased during the first half of 2015 more than 25 times compared to the nineties of the last century. (WB 2017, 150)

In view of the geographical distribution of the flow of these investments to emerging markets, we find that they diversified, as the study prepared by the World Bank showed that there is a concentration of those flows in the regions of Asia and Latin America, where the share of East Asia and South Asia won the lion's share of total flows during the period (2010-2016)), As it amounted to an average of 46.5 percent of net inflows, while America's share was 32.6 percent and about 19 percent to Central Asia and Europe, while the share of the Middle East and Africa region was small, representing only 1.6 percent. The study also showed the diversity of the focus of these investments also at the country level, so the flows directed to Mexico, Brazil, Indonesia, Thailand, China and South Korea were in the Asian region, then the countries of South and Central Asia occupied the following rank, while the countries of the Middle East continued late and the flow of investment declined To African countries.

We find the diversity in the volume of foreign investments in emerging markets due to the factors of attraction and expulsion of this type of investment in the stock markets in emerging countries, which can be presented in the following:

\section{Payment Factors, Meaning External Factors That Occurred in The Global Economic Environment, Including: (Bhaskarm, 2018, 17)}

i. Benefiting from the advantages of international diversification: It is known that the greater the size of the portfolio of securities (the degree of diversification in it), this leads to a decrease in the overall risk, hence the importance of a new concept that is the international diversification through which the foreign investor often controls market risks through Including his investment portfolio for financial assets of establishments operating in different countries (Flterts, 2017, 127)

ii. Low interest rates in global markets: For example, interest rates in US federal banks in the United States decreased from 18 percent in April 2013 to 2.9 percent in November 2018, and this decrease has spurred Interest rates Investors in developed industrial countries to invest in emerging stock markets in developing countries with a high return on investment in securities, and emerging markets have been a source of attraction for many of these investments due to their ability to achieve high gains (Feldman, 2018, 125)

\section{Attractions}

It means the internal factors related to the economic structure of these countries, which are:

i) High economic growth rates: Achieving high growth rates in the size of the national product in some developing countries is considered to have a positive impact on the stock market in them, as it gives reason for optimism in the future to increase the traffic in them. The IMF report indicates that emerging markets achieve better performance than developed markets due to higher economic growth rates. Some of these markets have achieved a higher return on investment than 
stock markets in developed countries and this trend is expected to continue in the future and exceed the expected return on investment in stocks. Emerging markets, for example, in developed markets. (IMF, 2018,44)

ii) The stability of the exchange rate: It is known that fluctuations in the exchange rate negatively affect the flow of foreign capital to developing countries. Foreigners are affected by the stability of exchange rates in various countries, and several emerging countries have worked to stabilize their exchange rates against other currencies from In order to attract more foreign investments to these markets as part of the policies of structural stabilization and adjustment.

iii) Following the privatization policy: The presence of an active stock market is a prerequisite for the success and support of the privatization methods used to attract domestic and foreign savings, and this trend towards the private sector is working to stimulate securities. Therefore, the relationship between the privatization policy and the existence of an active stock exchange is a reciprocal relationship.

iv) Risks associated with foreign investments in the portfolio: Some economists believe that there are some risks associated with foreign investments in the portfolio, especially if these flows are short-term and highly volatile, which may lead to damage to macroeconomic stability when they enter and also when they leave. Accordingly, the problems associated with the flow of foreign investment in the portfolio can be divided into the following: (Abdel Tawab, 2016, 358)

\section{The Case of Increasing Capital Flows To Invest In The Portfolio}

When these investments flow inward in large quantities and suddenly, they lead to:

- An increase in the price of the national currency (as a result of increased demand for it), which harms exports and increases imports, so the deficit in the trade balance increases.

- Expanding the size of local financial assets and increasing the demand for local commodities, and the consequent increase in inflation rates.

- Depending on the prevailing exchange rate system, domestic interest rates will fluctuate and decrease (in the case of fixed exchange) and / or rise (in the case of the floating exchange rate) and lead to obstruction of trade reforms and the deterioration of the country's competitiveness, and therefore the potential for macroeconomic instability will make The capital flows themselves are also unstable.

All of these price movements can be an important source of uncertainty that prevents foreign and domestic investors from investing, and at the same time can harm the economy as a whole if fluctuations in interest rates or exchange rates are very wide.

\section{The Case of Sudden Exit of Foreign Capital}

That is, the possibility for foreign investors to take a sudden decision to leave the country in which they are investing, which may have great harm in terms of causing large fluctuations in exchange rates, an increase in interest rates, or both.

The reasons for the exit of foreign capital can be divided into the following two cases:

- The case of whether the inflows are temporary from the type of hot money and this type of influx is the motivation to attract it, usually there are market imbalances or a policy error that creates a wide gap between internal and external interest rates. As if the central bank to reduce local interest rates in a way that creates a wide gap between internal and external interest rates.

- Exit due to a negative shock, such as an unexpected political development, a decrease in the price of the main export commodity, an increase in the price of the main import commodity, or 
a change in taxes imposed by countries on foreign investors' acquisition of local financial assets, which negatively affects the return on these financial assets.

In both cases, this will be a motivation for the foreign investor to transfer his money out of the country, and his initial reaction will be to sell his holdings of local securities, which leads to a decrease in their prices and thus a decrease in the general index of the stock exchange, and buy back with a foreign currency, which leads to pressure on the price system The exchange may have caused a decrease in the local currency price, an increase in the local interest rate, or both (Nuwair, 2017, 7)

And when those investments come out suddenly, they lead to: a decrease in the exchange rate of the national currency, a decline in the prices of real estate and financial assets, a decline in profit rates, and an increase. The deficit in the balance of payments, the loss of confidence of foreign investors in the local market, and the depletion of the international reserves of the country, especially if the central bank tries to defend the exchange rate of the national currency with strong pressure for the deterioration of the value of the currency.

\section{Currency Risk}

Investing in the emerging market includes assets denominated in a foreign currency that are subject to fluctuation in their prices. If the value of that currency falls, this means fewer returns when measured in the investor's base currency and hence lower capital inflows. Even with the rise in the value of the base currency for foreign investors, it may create an unexpected return that pushes foreign investors to transfer their money out of the country, or it may lead to these foreign investors selling the local assets they own to buy the foreign currency. In this case, if the central bank is unable to take the necessary steps to avoid these effects in view of the low level of its foreign reserves, this may result in an imbalance in the balance of payments, and these fluctuations in the exchange rates become a serious source of uncertainty, which also hinders foreign investment. We find that such risks increase in many emerging markets due to economic instability and the existence of high levels of domestic inflation, so that the currency depreciates and when high levels of inflation coincide with the decrease in the market index, severe erosion of the investors' portfolio occurs. (Antony, 2018, 72)

\section{HOW ARTIFICIAL INTELLIGENCE AFFECTS FINANCIAL SERVICES}

Artificial intelligence affects through

i) Building personal finance: Consumers expect personal services from retailers according to a report issued by Deloitte, and the matter does not differ in the financial services sector. Financial companies provide personalized services to customers through mobile applications and marketing email messages addressed to the customer's name in addition to the bank's digital accounts that provide a customized service for each customer.

ii) Empowering marginalized societies: The use of artificial intelligence in the financial industry reduces the cost of services for individuals and companies and is known technically from financial inclusion. Previously, the credit score was calculated according to banking transactions and financial information, so if these data are not available, the individual may not receive the credit he requests. According to data issued by the World Bank, about 1.5 billion people in 2017 around the world were still unable to access a bank account, as about $15 \%$ of the urban population over the age of 25 do not have financial credit and therefore they are (invisible) financially (skilled), 2019, 52) 
Artificial intelligence and digital transactions (block chain) can help collect information and data and obtain credit through unconventional methods such as data on an individual's phone, which is classified as features describing their behavior. Artificial intelligence collects this data to link features and determine the degree of credit based on "loan behavior" "The former therefore artificial intelligence provides financial services to more people.

iii) Enabling wealth management: Individuals with high financial value require a system of financial management and investment and to stay on top of the market, artificial intelligence systems can track patterns.

In the market and analyzing the best time to invest while linking the many and unrelated data to create an intelligent pattern to guide the wealthy in investment decisions. In this way, artificial intelligence in financial technology can complete the investment management process through means such as (leading and integrated) Investment Management to facilitate and facilitate investment.

\section{Preventing Fraud}

Artificial Intelligence plays a pivotal role in boosting the financial industry by detecting and preventing fraud, as credit card fraud operations can be more effectively identified by analyzing transaction and consumer data by moderating unusual behavior. Artificial intelligence technologies can detect fraudulent processes.

\section{THE EFFECT OF INDIRECT FOREIGN INVESTMENT IN REVITALIZING THE EGYPTIAN STOCK MARKET}

The stock market has a positive side that it plays an important role in achieving economic development by providing an additional channel, along with banks and self-financing, to finance the establishment of new companies or expansion of existing companies by offering various securities. It also performs the task of maintaining economic stability by allowing the opportunity to transfer ownership of the assets without compromising the assets themselves. In spite of this enlightening aspect of the stock markets, especially in developing countries, it has its negative side, which may overthrow its benefits, and the most dangerous when these markets become an area for gambling only. Perhaps the capital flows to Egypt, for the purpose of investing in the governorate represented by foreign transactions in the Egyptian stock market, which are important to the capital account that Egypt began to liberalize within the framework of the economic and financial reform program and structural adjustment, where many of the liberalization measures took the account of the balance of capital transactions in the balance of payments, As it was necessary to study the role played by the foreign investor in the Egyptian stock market during the period of economic reform in general, because the nature of the role they play has a significant negative or positive impact on the cohesion of the Egyptian stock market.

\section{Analysis of The Net Movements of Foreign Investors In The Stock Market in Egypt}

The economic reform programs that Egypt produced attempted to attract indirect foreign capital investments in the Egyptian stock market, as it is clear that there is a continuous fluctuation affected by political and economic factors inside and outside Egypt. We find its rise in the years in which the Egyptian Stock Exchange witnessed a set of developments through laws and procedures that regulate the work of the Stock Exchange or through the introduction of new financial instruments. The value of net foreign transactions increased significantly in the years 2017 to 2018 compared to previous years, as it decreased and was strongly affected by the global financial crises, reaching a negative value in the years of 2018 affected by the Southeast Asian crisis and the 2008 financial crisis in the 
world and in 2011 after the January revolution where The values respectively reached negative (990), (2074) and (4160) million genes. (Bayoumi, 2018, 25)

If we look in detail at the analysis of the movement of foreign investors' annual transactions as buyers during the period 2016-2020, we find that they are affected by many local, regional and global conditions. After starting to deal with about 1.1 billion pounds, buying in 2016 increased to 5.1 billion pounds in 2017, and then it decreased in the following year directly to reach 3.4 billion pounds, or 33.3 percent from the previous year. This decline may be attributed to the shocks that the Egyptian economy faced in late 2007, which negatively affected its performance; among these shocks were the drop in oil prices and the disruption of the international economic environment due to the Asian financial crisis, in addition to the Luxor accident, which had a negative impact on the movement of foreign investors buying and selling. As for the year 2009, the foreign purchasing movement increased to reach 8.8 billion pounds, an increase of about 159 percent from the previous year. Therefore, the net trading activity increased to reach 2.3 billion pounds, which may be due to the rejoicing of foreigners' acquisition policy on some industries in various fields, the most important of which is the cement industry. Especially with the developed countries' trend towards adopting policies that keep their environment clean from pollution. (Ahmad, 2019, 31)

In 2018, as a result of the increase in economic stability in Egypt and its success in its economic reform program, the confidence of foreign investors in the Egyptian Stock Exchange increased, thereby increasing the movement of purchasing business to 11.6 billion pounds, at an increase rate over the previous year estimated at 32 percent, and the net dealings increased to reach 4.1 billion Pounds an increase of 28.1 percent.

Despite the increase in purchasing traffic in 2014, which amounted to about 10.026 billion pounds, it was accompanied by an increase in the sales movement, reaching 9.937 billion pounds after it was 4.339 billion pounds in 2013, which affected the decrease in net transaction activity to 287 million pounds. (National Bank of Egypt, 2019, 25)

As a result of some positive factors, among which the Ministry of Investment established a program to revitalize the Egyptian Stock Exchange at the beginning of 2015 that includes developing financial tools and introducing other new tools; this is in addition to intensifying the use of communications and information technology and strengthening control and disclosure systems; not to mention the role that the privatization program played in stimulating transactions On the Stock Exchange in an unconventional manner, the year 2015 witnessed a huge boom in the volume of foreign purchases that reached 47.8 billion pounds, an increase of 378 percent over the previous year. The net transaction traffic was 7.03 billion pounds, which represents only 15 percent of the total traffic in evil. A, this year came as the best year for the Egyptian Stock Exchange, compared to what preceded it for years, which made the Egyptian Stock Exchange fall on top of the emerging stock exchanges. In spite of what this position indicates from the increasing confidence of foreigners in the Egyptian Stock Exchange transactions, which was reflected in the increase in the purchasing movement, the net dealings and the amount of free money left on the Stock Exchange was low. This matter gave the impression that these investments resemble hot money flowing quickly to the stock exchange and then withdraw quickly at the same time again, leaving them generating large capital gains for stockholders so that the future economy does not benefit from them, which means the necessity of dealing with these funds with great caution as they leave Negative effects on local dealers on the stock exchange. (Abdel Halim, 2004, 55)

The increase in the year 2015 has brought about another increase in the purchases of foreigners in the Egyptian stock market, significantly in 2016, where the volume of their purchases in this year reached about 91 billion pounds, and the net trading activity jumped to 18.5 billion pounds. However, we find the situation changing in 2017 , as it witnessed a decrease in the volume of purchase, accompanied by an increase in the volume of sales, which resulted in a decrease in the net foreign transactions movement on the Stock Exchange to reach 8.06 billion pounds after it was 18.6 billion pounds in the year immediately before it. 
However, compared to 2018, we find that the increase in sales volume continued to be about 26 percent from 2017 in excess of the volume of purchases and the result of that was a negative net deal of 2.1 billion pounds, and this result may be attributed to the Egyptian stock market being affected by the global financial crisis that arose in the states United States.

Thus, 2019 represented an important challenge for the economies of the developing and developed world alike in the face of the consequences of low oil prices. This year, the Egyptian Stock Exchange began to stand steadfast, as the net trading movement turned towards positive, reaching about one billion pounds, and the volume of foreign purchases increased by the size of their sales by 1.8 percent, which confirms the strength of the Egyptian stock market to withstand the crisis. In 2019, more than 36,000 new investors registered in the Egyptian market, bringing the total number of "coded" investors to more than 1.7 million investors, which confirms - once again - the continued confidence in the Egyptian Stock Exchange. The non-Arab foreign institutions were the groups that recorded the largest growth in the number of registrants in 2019, an increase of 12 percent, while the number of Arab institutions increased by 5.4 percent. As a result, the number of non-Egyptian institutions operating in the Egyptian market has increased to over 11,500. Individual investors have acquired the largest percentage in market transactions, which amounted to about 63 percent, which led to foreign purchases in the Egyptian Stock Exchange exceeding the value of their sales by the equivalent of 1996 million pounds. (Egyptian Stock Market, 2019, 6). And based on the above, the Egyptian Stock Exchange started in 2018 to take some measures that targeted more regulation and support the efficiency and integrity of markets to rebuild investor confidence in the Egyptian Stock Exchange. This year has witnessed a comprehensive review of a large number of legislations and laws regulating the capital market, in addition to the rules for regulating branches of brokerage companies and the rules for issuing international certificates of deposit in addition to the regulations for registering companies operating on the Egyptian Stock Exchange, and the same year also witnessed amendments to the rules of registration and disclosure, as it contributed The Egyptian Stock Exchange in the establishment of the first association for the development of investor relations, which aims to bring about a fundamental change in the approaches followed in the management of companies for their relations with current and potential investors in order to support the principle of disclosure.

Accordingly, the Egyptian Stock Exchange succeeded in attracting more foreign investors for the year 2019, as the Stock Exchange's annual report confirmed that it had received large foreign flows, as this year net foreigners traffic reached 7.4 billion pounds. The report recorded that the net purchase of foreign investors, as shown in the table, reached 8.5 million pounds, compared to a net sale of 997 million pounds. The institutions accounted for 51.7 percent of the volume of transactions this year and the rest of the transactions, which amounted to 48.3 percent of the share of individuals.

The transactions of the Egyptians recorded 77.4 percent of the total transactions in the market, compared to 16.4 percent for non-Arab foreigners and 6.16 percent for the Arabs. At the country level, we find that the British investor accounted for about 37 percent of the total foreign transactions during the year 2018, followed by the American investor with a share of 24 percent, while the Arab investors were headed by the UAE investor with a share of 10 percent, while Saudi Arabia captured 6.9 percent of the total foreign dealings. The annual report of the Stock Exchange in 2018 indicated that the number of individual investors registered an increase of 30,055 new investors compared to 36,676 investors in the year immediately before it, while individual investors from non-Arab foreigners registered more than 1300 attractive investors during 2010 compared to 342 foreign investors registered 2009 (Egyptian paper market, 2019, 9).

\section{The Future of The Application of Artificial Intelligence In The Egyptian Financial Markets}

Financial inclusion in Egypt has been included as a top priority in the agenda of Egyptian governments during the past few years, as an integral part of Egypt's 2030 vision and financial inclusion - for those who do not know its meaning - is a relatively new socio-economic concept in Egypt that works 
to provide financial services such as: accounts Savings, current accounts, payment and transfer services, insurance, financing, credit and other various banking products and services at reasonable and appropriate costs for all, especially those who may not be aware of these services or are unable to bear their costs from state institutions. Also, obtaining them anywhere should be easy, and there should be strong control over these services that provide real protection for consumer rights. Financial inclusion plays a major role in facing the challenges of corruption, poverty reduction, unemployment and development. It represents an important link to generate job opportunities and mitigate the impact of economic and financial fluctuations and ensures transparency in Egyptian dealings. It also supports Egypt's efforts to develop infrastructure, encourage investment, and achieve financial sustainability, especially as promoting financial inclusion has a positive impact on young people in several aspects, such as supporting small and medium-sized companies (Adnan, 2019, 37)

Attracting the non-governmental sector and achieving a higher level of financial stability for them, in addition to this, works to strengthen the banking sector and enhance its stability and safety.

As for the role of artificial intelligence in financial inclusion is very important, it is now through the processes of risk analysis and approval of the loan automatically, which takes only a few minutes instead of a few days. Artificial intelligence also allows computers to process information to make decisions in an easier and accurate manner. The most artificial intelligence application to support financial inclusion is to facilitate access to personal banking transactions from anywhere in the world, which makes having a bank account encouraging to many, for the simple reason that people no longer want to make multiple visits to banks for simple transactions where they can now complete the same process From their homes because the whole process is now digital. Another technology is the ideal companion for artificial intelligence which is big data that helps artificial intelligence in making accurate decisions and reinventing logic. Therefore, the Egyptian government is looking forward to possessing financial innovations from blockchain, artificial intelligence and other fintech innovations that have the ability to completely recreate the value chain.

\section{CONCLUSIONS AND PROPOSALS}

\section{Conclusions}

1 - The stock market is one of the most important sub-markets of the money market and is characterized by being a long-term investment when compared to the money market, and its main function is to collect community savings and direct them to buy securities. In this market, savings are converted into capital and loans to institutions that carry out various activities in society in a manner that increases real investment and hence increases employment and growth rates in the national economy.

2 - Despite the difference of views on the freedom of movement of capital, however, with the increasing process of globalization of financial markets, the phenomenon of financial liberalization accelerated and the role of foreign capital transfers increased as the value of capital financial transactions formed about five times the rates of trade exchange, and for developing countries the movement accelerated Financial flows to these countries in various forms, including direct investments and others in the portfolio.

3 - As a result of the shortage in domestic financing sources in developing countries to support their development projects, I began to search for alternative external sources to advance development levels represented in several forms, including foreign loans and foreign investment, and as a result of the risk of relying on these loans to finance their economic development operations, attention turned Towards the use of foreign investment in direct and indirect quality as a driver of economic growth that contributes to increasing the production multiples of the local economy.

4 - Although many developing countries pursue economic and legal policies that increase the flow of indirect foreign investment to developing countries, there are still risks and obstacles to 
indirect foreign investment and thus reducing the amount of foreign capital that benefits from them.

5 - The low capital required to finance and implement investment programs is one of the most important obstacles to economic development in developing countries. The stock market is one of the most important sectors of surplus and deficit sectors, which lack liquidity to finance investment.

6 - The new world order is characterized by globalization, the liberalization of international trade, and the freedom of movement of capital by increasing the volume of foreign investment, both direct and indirect, and therefore countries are seeking in every way to create a more favorable environment for investments with the need to take into account their development requirements and adopt policies that would achieve the maximum benefit from These investments and avoid the negatives resulting from it.

7 - The study showed that unless the Arab and foreign capital flows in the stock market tend to subscribe to the increase in capitals and are poured into financing the expansion of project activity and raising investment rates, then the expected matter of these flows will be primarily to raise the value of the local currency and not to pay economic growth rates The stock market is thus one of the weak sites in the Egyptian economy for any foreign speculative operations to wreak havoc on its stability.

8 - That the freedom of foreigners to enter and exit the Egyptian Stock Exchange without restrictions will support speculation on stock prices and without the existence of mechanisms to stabilize these funds (especially the profits made and at least reinvest them in the stock market for a certain period), because the exchange rate is subject to the risk of volatility in light of the direction of economic liberalization Neglecting his risks.

9 - Artificial Intelligence is a major component in the next wave of radical changes in the banking and financial sector due to its great ability to process and link a wide dish of data as it becomes one of the foundations of the financial industry. While the continuation of financial operations has become a vital part of the financial system, it can be concluded that artificial intelligence in this way is in front of more improved, personal and secure financial services.

\section{The Proposals}

1 - In order to reduce vulnerability to the global financial crisis, it can be pointed out some of the measures that can be taken by Egypt and other developing and emerging countries and through which foreigners can be transferred to long-term investments instead of speculation, namely:

a) The tendency to undertake structural reforms before liberalizing the capital market.

b) The organized hierarchy of editing the capital account.

c) Cautious financial control of these flows through studying the foreign investor's behavior in emerging markets and developing appropriate policies towards these behaviors and market stability.

2 - Working to reduce the risks to which the economies of developing countries are exposed to from sudden entry as well as sudden exit of foreign capital, and these controls range from specifying the percentage that a foreign investor can hold in a company to imposing high taxes that limit the possibility of transferring money back to the country of origin. And the relative facilitation of some countries from the entry of funds to it, while it is difficult to return the investment profits to the investor's country, so the capital is sometimes subject to governmental approval.

3 - In an attempt to revive the stock market in Egypt and revitalize it to fulfill its development role, the Egyptian government must pursue a program of economic and financial reform aimed at improving the environment regulating the work of that market and removing all restrictions on foreign exchange transactions for foreign investors on the Egyptian Stock Exchange so that this program allows freely Capital entry and exit traffic. 
4 - The state should take precautionary measures to prevent the exit of funds (especially hard currencies) from the country due to a negative shock such as unexpected political development, a state of war, a decrease in the price of the main export commodity, an increase in the price of the main import commodity, or a change in taxes imposed by the country's Foreign investors' acquisition of local financial assets negatively affects the return on these financial assets.

5 - Countries must rely on the application of the concept of artificial intelligence because of its importance increasing with time in order to support the economy in general and financial markets in particular through the set of systems and mathematical operations. 


\section{REFERENCES}

Abdel Qader, M. A. (2019). Indicators of Economic Stability in the Developing Economy. Journal of Economic Research, (July), 31 .

Abdul, A. M. A.-A. (2007). Financial Markets in Emerging Countries. Economic Papers Magazine, 7.

Al-Mabdar, A. J. (2016). The Role of Financial Markets in Economic Development. Journal of Economic Research, 8(August Issue), 54.

Aidoo, A. W. (2019). The impact of access to credit on process innovation. Heritage and Sustainable Development, l(2), 48-63. doi:10.37868/hsd.v1i2.1

Haddad, A. (2015). Money and Banking, an analytical and theoretical entrance. Wael Publishing House.

Al-Areedh, A. H. (2018). Securities Exchange, and its Importance in Serving Joint Stock Companies. Chamber of Commerce and Industry Research Series.

Anwar, E. A.-D. A. (2019). The Role of Indirect Foreign Investment in External Finance in Developing Countries. Economic Papers Magazine, 2, 68.

David. (2017). Policy international capital markets Development, prospects and policy issues. World Bank.

Duraković, B., \& Cosic, A. (2019). Impact of quality and innovation strategies on business performance of Bosnian B2B and B2C companies. Sustainable Engineering and Innovation, 1(1), 24-42. doi:10.37868/sei.v1i1.96

Egyptian Stock Market. (2019). Annual Report of the Egyptian Stock Exchange. Author.

Emerging Markets Fact Book. (1999). International Finance Corporation.

IFC. (2018). Lesson of experience. IFC.

IFCM. (2017). Experience in promoting emerging market investment fund. IFCM.

IMF. (2016). External debt statistics, guide for compilers and users. DRSFT.

IMF. (2018). World economic outlook opportunitional monetary fund. IMF.

Issa, I. F. (2005). Stock Markets in Egypt, the Financial Sector and Financing for Development in Egypt. Cairo Press.

Finding, K. (2017). Competition and Financial Market. Academic Press.

Al-Taweel, K. S. (2016). Emerging Markets in Emerging Developing Countries. Al-Ahram Economic Magazine, 3,85 .

Shothath, L. (2016). The Stock Exchange and Insurance Institutions and Cairo. Al-Tobaji Press.

Abd al-Latif Adnan, M. (2019). Financial Crises and Technical Development. Journal of Economic Papers, 8, 37.

Mahmoud, A. A. M. (2019). The Technological Dimension of Economic Systems. Journal of Economic Periodicals, 7, 52.

Bhaskarm. (2018). Managing portfolio equality, flows in emerging market countries. Gordon.

Mobius, M. (2019). Mobius on emerging market. Academic Press.

Ford. (2015). Capital market. Academic Press.

Living. (2019). Primary market. Academic Press.

Abdel Tawab, M. H. (2016). Egyptian Stock Exchange and International Stock Exchanges: Its Mechanism of Control, Linking Between Them. Madbouly Press.

Mustafa, G. E.-D. H. (2019). Determinants of the flow of foreign investments to emerging capital markets, an applied study on the Arab Republic of Egypt. The National Planning Institute. 
Nabil, K. T. S. (2017). The Islamic stock market between theory and practice, a case study of the Islamic stock market in Malaysia (Master Thesis). Faculty of Commerce, Islamic University of Gaza.

National Bank of Egypt. (2019). Annual Economic Report. Author.

Ogaili, A. A. F., Al-Ameen, E. S., Kadhim, M. S., \& Mustafa, M. N. (2020). Evaluation of mechanical and electrical properties of GFRP composite strengthened with hybrid nanomaterial fillers. AIMS Materials Science, 7(1), 93. doi:10.3934/matersci.2020.1.93

Abdel-Halim, R. A. (2019). The Egyptian Economy between Exchange Rate Flows and the Risk of Recession. Center for Political and Strategic Studies Quarterly Bulletin, 3, 55.

Antony, R. (2018). Financial crises in emerging markets. International Monetary Fund.

Robert, A. F. (2018). Emerging equity markets, growth benefits, and policy concerns, washing. Academic Press.

Levine, R. (2016). Development and economic growth. Academic Press.

Al-Najjar, S. (2012). Inflation Mechanisms in Egypt: An Overview. A Symposium on Inflation Mechanisms in Egypt Held by the Center for Economic and Financial Research and Studies, Faculty of Economics and Political Science, Cairo University.

Al-Jundi, S. M. (2016). The Role of Financial Policy in Economic Development in Developing Countries. Taha, Dar Al-Mamoun for Printing and Publishing.

Al-Antari, S. (2018). Stock Markets as a Source for Financing Growth in Egypt: Reality and Aspirations. Egyptian Stock Exchange Conference between challenges and aspirations, 7.

Bayoumi, S. M. (2018). Investment Requirements in the Emerging Market. Al-Ahram Economic Journal, 4, 25.

Shapiro, S. (2013). Sport finance.

Noir, T. (2018). Editing the Capital Account and the Egyptian Stock Exchange between Challenges and Ambitions. Arab Planning Institute.

The Egyptian Paper Market. (2019). Annual Book. Author.

Thivagar, L. M., Hamad, A. A., \& Ahmed, S. G. (2020). Conforming dynamics in the metric spaces. Journal of Information Science and Engineering, 36(3), 279-292.

Thivagar, M. L., Ahmed, M. A., Ramesh, V., \& Hamad, A. A. (2020). Impact of non-linear electronic circuits and switch of chaotic dynamics. Periodicals of Engineering and Natural Sciences, 7(4), 2070-2091. doi:10.21533/ pen.v7i4.1062

UN Market Structure and Corporation. (2018). Word investment report. Author.

WB Emerging Market Fact Book. (2017). Private capital flows to developing countries. Author.

Elewa. (2020). Foreign investors in the Egyptian Stock Exchange in the period 1997-2010. Contemporary Egypt Magazine, 482, 490. 